\title{
PENGARUH PENGUNGKAPAN CORPORATE SOCIAL RESPONSIBILITY TERHADAP KINERJA KEUANGAN PADA PERUSAHAAN SEKTOR PERBANKAN
}

\author{
Oleh : \\ Ivena Melinda \\ Manajemen - Sekolah Tinggi Ilmu Ekonomi Harapan Bangsa \\ E-mail: Ivena910@yahoo.co.id \\ Mentiana Sibarani \\ Manajemen - Sekolah Tinggi Ilmu Ekonomi Harapan Bangsa \\ E-mail: Mentiana@ithb.ac.id
}

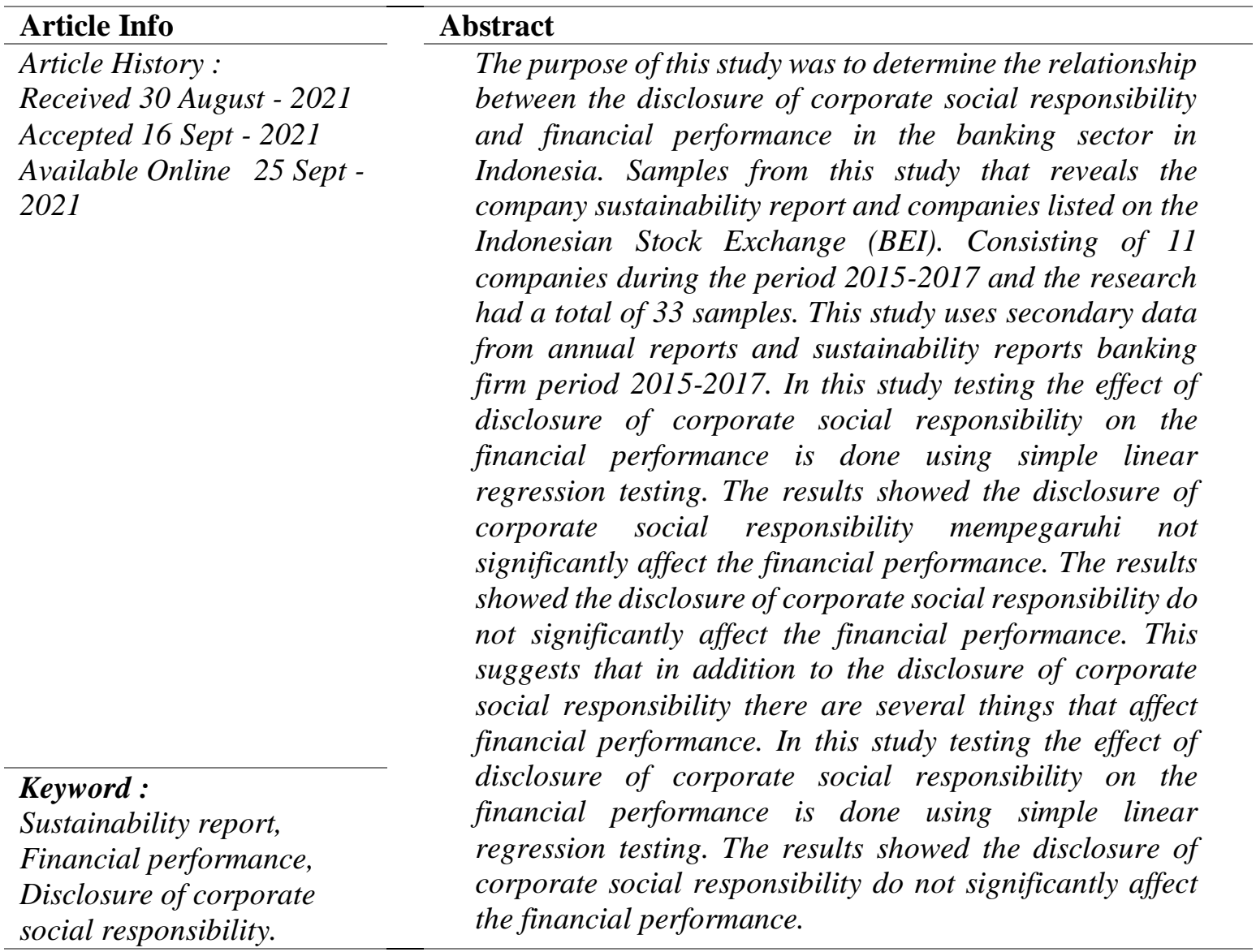




\section{PENDAHULUAN}

Perusahaan adalah organisasi yang didirikan oleh seseorang atau sekelompok orang atau badan lain yang kegiatannya melakukan produksi dan distribusi dengan tujuan utama pendirian perusahaan adalah creating value. Dimana creating value adalah proses penciptaan nilai yang dilakukan perusahaan secara efektif dan efisien untuk memaksimalkan profit bagi perusahaan dan para shareholder (Bank Indonesia, VII, 2017, p. 4). Keberlanjutan perusahaan sangat penting karena menjadi salah satu pertimbangan para investor dalam berinvestasi. Keberlanjutan perusahaan dapat dilihat melalui kinerja keuangan dari perusahaan.

Kinerja keuangan pada perusahaan yang bergerak di bidang keuangan cenderung mengalami peningkatan dari tahun 2015 sampai dengan 2017 dimulai dengan pasar modal yang kinerja keuangannya membaik dari tahun 2015 sampai dengan 2017 dikarenakan IHSG yang terus naik mencapai rekor tertingginya. Perusahaan multifinance menunjukkan kinerja keuangan yang terus membaik dari 2015 sampai dengan 2017. Pada tahun 2015 laba industri multifinance anjlok 17,20\%, dalam hal ini ada 83 perusahaan pembiayaan yang menyumbang penurunan itu. Sektor pembiayaan jadi bisnis yang paling terkena imbas stagnasi adalah pasar otomotif karena penjualan domestik kendaraan bermotor menjadi lahan utama pasar pembiayaan atau multifinance. Pada 2016, secara industri pertumbuhan multifinance lebih baik dengan pertumbuhan pembiayaan sebesar $6,67 \%$ dan labanya naik $12,27 \%$. Namun, banyak perusahaan multifinance yang kinerjanya tetap memerah karena sudah terkuras di tahun sebelumnya sehingga gagal memanfaatkan pertumbuhan positif industrinya. Pada tahun 2017 perusahaan pembiayaan mencatat laba bersih sebesar Rp9,76 triliun atau mengalami pertumbuhan laba sebesar $8,73 \%$. Pada perusahaan asuransi kinerja perusahaan asuransi mengalami pertumbuhan Menurut Asosiasi Asuransi Umum Indonesia (AAUI) dikarenakan peningkatan premi bruto asuransi di setiap tahunnya. Pada perusahaan perbankan kinerja keuangannya baik terbukti dari di tengah perlambatan industri kita, beberapa indikator kesehatan perbankan masih terjaga dengan baik walaupun loan to deposit ratio (LDR) industri perbankan berada di angka yang cenderung tinggi. Pelambatan kredit terjadi tentu menjadi masalah pada perbankan karena kredit merupakan salah satu sumber pendapatan bagi perusahaan perbankan. Walaupun terjadi perlambatan kredit, menurut Deputi Direktur Departemen Pengambangan Pengawasan dan Manajemen Krisis OJK Bapak Aslan Lubis kondisi perbankan masih sangat solid dan sangat jauh dari krisis. Jika dilihat hanya dari kinerja keuangan saja maka perusahaan sektor perbankan akan menjadi salah satu sektor yang akan dipertimbangkan para investor dalam berinvestasi dikarenakan perusahaan sektor perbankan memiliki kinerja keuangan yang baik. Akan tetapi seiring dengan perkembangan bisnis dan jaman yang semakin moderen seperti sekarang ini keberlanjutan perusahaan tidak akan terjamin bila hanya berorientasi pada maximizing profit saja, tetapi perusahaan juga dituntut harus mementingkan kepentingan stakeholder selain aspek financial. Perusahaan hendaknya merubah citra perusahaan mereka menjadi sebuah perusahaan yang memiliki komitmen yang tinggi dalam melakukan tanggung jawab sosial terhadap masyarakat dan lingkungan. Salah satu upaya yang dapat dilakukan perusahaan untuk melakukan tanggung jawab sosial adalah dengan melakukan program CSR (Corporate Social Responsibility).

CSR adalah kepedulian perusahaan terhadap lingkungan dan sosialnya, dimana perusahaan harus memberikan dampak yang positif bagi masyarakat dan dengan cara yang produktif sebagai akibat dari eksploitasi SDA (Sumber Daya Alam) untuk kebutuhan bahan baku produksinya sehingga banyak terjadi kerusakan lingkungan yang disebabkan dari eksploitasi SDA tersebut seperti contohnya pencemaran air, dan lain - lain. Kesadaran akan pentingnya CSR yang dilakukan perusahaan mendorong 
perusahaan untuk mengungkapkan informasi mengenai kegiatan - kegiatan CSR (Social Disclosure) yang telah dilakukan guna menjadi sebuah daya saing perusahaan. Laporan mengenai kegiatan kegitan CSR yang dilakukan oleh perusahaan dapat dilihat pada laporan berkelanjutan (Sustainablity Report) dengan pedoman penyusunan menggunakan GRI. Pada tahun 2014 menggunakan GRI generasi ke-4 atau GRI G4 dan GRI mengeluarkan standards GRI 2016 terbaru yang mulai diterapkan untuk tahun 2017.

Informasi pada laporan sustainability report dibutuhkan oleh shareholder karena mengandung informasi tambahan untuk mengambil keputusan dalam melakukan investasi (Suciwati, et al. 2016).

Beberapa praktik CSR mulai dilakukan oleh perusahaan - perusahaan perbankan seperti bank BCA yang melakukan CSR dalam dunia pendidikan dengan program bakti BCA bekerja sama dengan Kidzania Pasific Place mengajak 500 siswa SD untuk mengenal perbankan sambil bermain di booth minibank BCA di Kidzania Pasific Place. Bank Mandiri juga melakukan praktik CSR dalam dunia pendidikan dengan memberikan perangkat keras Server AS/400 dan aplikasi core banking, perangkat lunak yang juga disediakan oleh IBM terdiri atas OS/400 V5R2, aplikasi Websphere Development Studio dan beberapa program lisensi yang dibutuhkan untuk mendukung jalannya aplikasi core tersebut perguruan tinggi yang akan menerima bantuan ini adalah Universitas Indonesia (UI), Institut Teknologi Bandung (ITB), Universitas Hasanudin (Unhas), Universitas Gadjah Mada (UGM), Institut Teknologi Surabaya (ITS) dan Universitas Sumatera Utara (USU). Melalui kerjasama ini, pihaknya berharap perguruan tinggi dapat menyediakan pendidikan bermutu tinggi guna memenuhi kebutuhan tenaga kerja profesional di bidang TI perbankan lalu Mandiri dan IBM juga akan membantu universitas dalam memberikan pelatihan bagi para dosen, melaksanakan instalasi fasilitas dan mengembangkan materi kuliah bagi para mahasiswa. Bank Mandiri menyadari akan dibutuhkannya tenaga terampil di bidang TI perbankan dalam jumlah yang banyak dan melalui penerapa CSR pada Bank Mandiri berharap dapat menjembatani kesenjangan antara demand dan supply tenaga siap pakai di bidang TI perbankan. Hal yang berbeda dalam praktik CSR yang dilakukan oleh Bank BNI dengan mewujudkan korporatisasi petani dan BUMDes dengan tujuan pengembangan kawasan transmigrasi, yakni menjadikan kawasan transmigrasi sebagai pusat pertumbuhan. Target tersebut diraih melalui pengelolaan sumber daya alam yang berkelanjutan sebagai perwujudan implementasi Nawacita ke-3 Membangun Indonesia dari Pinggiran. Saat ini, BNI telah mengembangkan 19 BUMDes di Mesuji yang telah memiliki aktifitas usaha. Setiap BUMDes ditingkatkan kapasitasnya agardapat menjadi agen bank yang di BNI disebut Agen46. Status Agen46 tersebut memperkaya layanan BUMDes tersebut yang sebelumnya sudah menjadi agen pupuk/pengecer pupuk, sebagai pengelola pasar, listrik/air desa, hingga penyedia jasa transportasi. Untuk memperkuat pertanian di Mesuji, BNI juga menggelontorkan bantuan Corporate Social Responsibility (CSR). Pada acara di Desa Wonosari ini, BNI memberikan 19 handtractor untuk digunakan petani di 19 BUMDes yang telah berstatus sebagai Agen46. BNI juga menyalurkan Kredit Usaha Rakyat (KUR) sebagai bagian terintegrasi dari dukungan korporasi pada pengembangan sektor pertanian di Mesuji dan sekitarnya. Dana Desa tersebut dapat dimanfaatkan untuk memenuhi kebutuhan pembangunan desa termasuk digunakan untuk 4 Program Prioritas Pembangunan Desa yaitu : PRUKADES, Embung, BUM Desa, dan Sarana Olahraga Desa.

\section{KAJIAN PUSTAKA DAN PENGEMBANGAN HIPOTESIS Teori Stakeholder}

stakeholder theory artinya sebagai kumpulan kebijakan dan praktik yang berhubungan dengan stakeholder, nilainilai, pemenuhan ketentuan hukum, penghargaan masyarakat dan lingkungan, serta komitmen dunia usaha untuk berkontribusi dalam pembangunan secara berkelanjutan. Stakeholder theory dimulai dengan asumsi bahwa nilai secara eksplisit 
dan tak dipungkiri merupakan bagian dari kegiatan usaha (Freeman R. e., 2010).

\section{Teori Signal}

isyarat atau signal adalah suatu tindakan yang diambil perusahaan untuk memberi petunjuk bagi investor tentang bagaimana manajemen memandang prospek perusahaan. Sinyal ini berupa informasi mengenai apa yang sudah dilakukan oleh manajemen untuk merealisasikan keinginan pemilik. Informasi yang dikeluarkan oleh perusahaan merupakan hal yang penting, karena pengaruhnya terhadap keputusan investasi pihak diluar perusahaan. Informasi tersebut penting bagi investor dan pelaku bisnis karena informasi pada hakekatnya menyajikan keterangan, catatan atau gambaran, baik untuk keadaan masa lalu, saat ini maupun masa yang akan datang bagi kelangsungan hidup perusahaan dan bagaimana efeknya pada perusahaan. (Brigham dan Houston, 2001).

\section{Teori Legitmasi}

Menurut Ghozali dan Chariri (2016) mengungkapkan definisi teori legitimasi sebagai suatu kondisi atau status, yang ada ketika suatu sistem nilai perusahaan sejalan dengan sistem nilai dari sistem sosial yang lebih besar di mana perusahaan merupakan bagiannya. Ketika suatu perbedaan yang nyata atau potensial, ada antara kedua sistem nilai tersebut, maka akan muncul ancaman terhadap legitimasi perusahaan.

\section{Corporate Social Responsibility}

Kotler dan Lee (2005) mendefinisikan terminologi Corporate Social Responsibillty sebagai : " $a$ commitment to improve community wellbeing through discretionary business and contributions of corporate resources".Definisi tersebut tidaklah semata mengacu pada aktivitas bisnis yang patuh pada hukum atau sebatas pada moral dan etika. Namun, lebih dimaksudkan sebagai komitmen sukarela yang dibuat oleh organisasi bisnis dalam memilih dan menerapkan praktek tanggung jawab sosial serta berkontribusi pada masyarakat. Komitmen tersebut, menurut Kotler dan Lee, harus ditunjukkan agar perusahaan dinilai sebagai organisasi yang secara sosial bertanggung jawab dan akan menjalankan praktek bisnis yang berdasar prinsip tanggung jawab sosial tersebut, baik secara moneter atau non-moneter. Istilah community well-being dalam definisi Kotler dan Lee tersebut memasukkan kondisi manusia sebagai anggota masyarakat, sebagaimana juga masalah lingkungan.

\section{Corporate Social Responsibility (CSR) \& Global Reporting Initiave's Sustainability Reporting Guidelines \\ Corporate Social Responsibility}

(CSR) secara eksplisit berarti melakukan bisnis dengan cara yang etis dan untuk kepentingan masyarakat luas, menanggapi dengan positif dan mengutamakan harapan prioritas sosial yang muncul, menyeimbangkan kepentingan pemegang saham terhadap kepentingan masyarakat luas serta menjadi warga negara yang baik di masyarakat. Dengan kata lain CSR adalah tentang kewajiban organisasi untuk semua stakeholder, bukan hanya pemegang saham. Berikut merupakan empat dimensi CSR:

a. Tanggungjawab ekonomi, untuk mendapatkan keuntungan bagi pemilik.

b. Tanggungjawab hukum, untuk mematuhi hukum.

c. Tanggungjawab etis, yang tidak hanya mencari keuntungan, tetapi melakukan apa yang benar, wajar, dan adil.

d. Tanggungjawab filantropis, untuk mempromosikan kesejahteraan manusia dan berniat baik.

Berdasarkan pedoman GRI G4 yang digunakan perusahaan dalam membuat sustainability report pada tahun 2014 sampai dengan 2016, terdapat 91 item yang tersebar pada tiga kategori utama. Dengan indikator inilah informasi pengungkapan CSR pada laporan tahunan perusahaan diukur melalui pemberian skor. Pengukuran variabel pengungkapan CSR kemudian disebut sebagai Corporate Social Disclosure Index (CSDI).

\section{Kinerja keuangan}

Kinerja keuangan adalah suatu analisis yang dilakukan untuk melihat sejauh mana perusahaan telah melaksanakan dengan baik serta menggunakan aturan-aturan pelaksanaan pengelolaan keuangan secara baik dan benar. 


\section{Rasio Keuangan}

Harahap (Harahap, 2015) mengemukakan bahwa rasio keuangan adalah angka yang diperoleh dari hasil perbandingan dari satu pos laporan keuangan dengan pos lainnya yang mempunyai hubungan yang relevan dan signifikan. Kesimpulan dari beberapa definisi bahwa analisis rasio keuangan merupakan suatu teknik analisis untuk mengevaluasi kondisi kinerja sebuah perusahaan dengan melakukan analisis pada laporan keuangan perusahaan tersebut.

\section{Tingkat Kesehatan Bank}

Kasmir (2016) mengatakan bahwa"Tingkat kesehatan bank dapat diartikan sebagai kemampuan suatu bank untuk melakukan kegiatan operasional perbankan secara normal dan mampu memenuhi semua kewajibannya dengan baik dengan cara-cara yang sesuai dengan peraturan perbankan yang berlaku. Pelaksanaan penilaian dilakukan dengan cara mengkualifikasikan beberapa komponen dari masing-masing faktor yaitu komponen :

$$
\begin{aligned}
& \text { Aspek Permodalan (Capital) } \\
& \text { Modal adalah uang yang }
\end{aligned}
$$
ditanamkan oleh pemiliknya sebagai pokok untuk memulai usaha maupun untuk memperluas (besar) usahanya yang dapat menghasilkan sesuatu guna menambah kekayaan. Adapun fungsi modal adalah (1) untuk mengukur kemampuan bank dalam menyerap kerugian-kerugian yang tidak dapat diharapkan, (2) sebagai sumber dana yang diperlukan untuk membiayai usaha, dan (3) sebagai alat pengukur besar kecilnya kekayaan bank atau kekayaan para pemegang saham. Dalam menilai aspek permodalan perbankan, salah satu rasio yang dapat digunakan menurut komponen yang ada dalam penilaian tingkat kesehatan bank adalah rasio CAR (Capital Adequacy Ratio). Tinggi rendahnya CAR suatu bank ditentukan oleh dua faktor yakni modal yang dimiliki dan jumlah Aktiva Tertimbang Menurut Risiko (ATMR).
b. Aspek Kualitas Aktiva (Asset Quality)
Aset adalah hal yang tidak kalah pentingnya dibandingkan dengan modal,

karena aset menopang jalannya usaha bank. Penilaian terhadap aset produktif adalah menggunakan rasio KAP (Kualitas Aset Produktif). Rasio KAP merupakan perbandingan aktiva produktif yang diklasifikasikan (APYD) dengan aktiva produktif. Aktiva produktif yang diklasifikasikan adalah aktiva produktif baik yang sudah maupun yang mengandung potensi tidak memberikan penghasilan atau menimbulkan kerugian, yang besarnya ditetapkan sebagai berikut:

1. 25\% dari Aktiva Produktif yang digolongkan Dalam Perhatian Khusus;

2. 50\% dari Aktiva Produktif yang digolongkan Kurang Lancar;

3. $75 \%$ dari Aktiva Produktif yang digolongkan Diragukan; dan

4. $100 \%$ dari Aktiva Produktif yang digolongkan Macet

c. Aspek Manajemen (Management) Penggunaan Net Profit Margin (NPM) juga erat kaitannya dengan aspekaspek manajemen yang dinilai, baik dalam manajemen maupun manajemen risiko, dimana net income dalam aspek manajemen umum mencerminkan pengukuran hasil dari strategi keputusan yang dijalankan dan dalam tekniknya dijabarkan dalam bentuk sistem pencatatan, pengamanan, dan pengawasan dari kegiatan operasional bank dalam upaya memperoleh operating income yang optimum. Sedangkan net income dalam manajemen risiko mencerminkan pengukuran terhadap upaya mengeliminir risiko likuiditas, risiko kredit, risiko operasional, risiko hukum, dan risiko pemilik dari kegiatan operasional bank, untuk memperoleh income yang optimum. d. Aspek Rentabilitas (Earning)

Rentabilitas (earnings) adalah suatu alat untuk mengukur kemampuan bank dalam menghasilkan laba dengan membandingkan laba dengan aktiva atau modal dalam periode tertentu. Laba yang besar bukanlah merupakan ukuran bahwa bank telah bekerja secara efisien. Efisiensi dapat diketahui dengan membandingkan laba yang diperoleh dengan kekayaan atau modal yang menghasilkan laba tersebut, atau dengan menghitung rentabilitasnya. Dalam menilai aspek rentabilitas, rasio yang dapat digunakan adalah rasio ROA (Return on Assets) dan BOPO (Biaya 
Operasional Pendapatan Operasional).

e. Aspek Likuiditas (Liquidity)

Likuiditas adalah kemampuan

bank untuk memenuhi kewajiban jangka

pendek. Suatu bank dianggap likuid apabila bank tersebut mempunyai kesanggupan untuk membayar penarikan giro, tabungan, deposito berjangka, pinjaman bank yang segera jatuh tempo, dan pemenuhan permintaan kredit tanpa adanya suatu penundaan (kredit yang direalisasi). Rasio yang digunakan dalam perhitungan likuiditas adalah rasio LDR (Loan to Deposit Ratio). Rasio LDR adalah perbandingan jumlah kredit yang diberikan dengan total dana pihak ketiga. Berdasarkan Peraturan Bank Indonesia No. 17/11/PBI/2015 tanggal 25 Juni 2015 tentang Perubahan Atas Peraturan Bank Indonesia Nomor 15/15/PBI/2013 Untuk mendorong pertumbuhan ekonomi yang dilakukan melalui pertumbuhan kredit perbankan, dilakukan penyesuaian melalui perhitungan loan to deposit ratio, yaitu dengan memasukkan komponen surat berharga yang diterbitkan bank dalam perhitungan loan to deposit ratio (LDR), sehingga formula LDR menjadi Kredit / (DPK + Surat Berharga Yang diterbitkan Bank). Seiring berubahnya formula LDR, maka istilah LDR diganti menjadi loan to funding ratio (LFR).

CAMEL merupakan faktor yang sangat menentukan predikat kesehatan suatu bank. Aspek tersebut satu dengan yang lainnya saling berkaitan dan tidak dapat dipisahkan. Untuk dapat menjalankan fungsinya serta menjaga tingkat kesehatan ,bank harus mempunyai modal yang cukup, menjaga kualitas asetnya dengan baik, dikelola dengan baik dan dioperasikan berdasarkan prinsip kehati-hatian, menghasilkan keuntungan yang cukup untuk mempertahankan kelangsungan usahanya, serta memelihara likuiditasnya sehingga dapat memenuhi kewajibannya setiap saat. Selain itu, suatu bank harus senantiasa memenuhi berbagai ketentuan dan aturan yang telah ditetapkan, yang pada dasarnya berupa berbagai ketentuan yang mengacu pada prinsip-prinsip kehati-hatian di bidang perbankan. Untuk itu, kesehatan suatu bank dapat dilihat dari laporan keuangan yang meliputi aspek-aspek tersebut.
Kinerja keuangan didapatkan dengan metode CAMEL yaitu dengan perhitungan total seluruh bobot nilai kredit CAMEL (max 100) dari rasio CAR, rasio $\mathrm{KAP}$, rasio NPM, rasio ROA, rasio BOPO, dan rasio LDR atau LFR. Rasio CAR didapatkan dengan perhitungan modal dibagi dengan aktiva tertimbang menurut resiko dikali $100 \%$ dan nilai kredit CAR didapatkan dengan cara 1 ditambahkan dengan rasio CAR dibagi dengan 0.1 . Rasio KAP didapatkan dengan perhitungan Aktiva Produktif yang diklasifikasikan dibagi dengan aktiva produktif da nilai kredit KAP didapatkan dengan cara 1 ditambahkan 15.5 dikurangi rasio KAP dibagi dengan 0.15. Rasio NPM didapatkan dengan cara laba bersih dibagi dengan laba operasional dilaki dengan $100 \%$ dan nilai kredit NPM sama dengan rasio NPM. Rasio ROA didapatkan dengan perhitungan laba sebelum pajak dibagi dengan total aktiva dikali $100 \%$ dan nilai kredit ROA didapatkan dengan cara rasio ROA dibagi dengan 0.015. Rasio BOPO didapatkan dengan cara perhitungan beban operasional dibagi dengan pendapatan operasional dikali dengan $100 \%$ dan nilai kredit BOPO didapatkan dengan cara $100 \%$ dikurangi dengan rasio BOPO lalu dibagi dengan 0.08. LDR didapatkan dengan perhitungan kredit yang diberikan dibagi dengan total dana pihak ketiga dibagi dengan $100 \%$ dan untuk tahun 2016 mulai ditetapkan oleh bank Indonesia bahwa LDR diganti dengan LFR dinyatakan dalam Peraturan Bank Indonesia pada tanggal 25 Juni 2015 tentang perubahan atas peraturan bank indonesia dengan perhitungannya yaitu kredit dibagi dengan total dana pihak ketiga ditambah surat berharga yang diterbitkan bank. Nilai kredit untuk LDR atau LFR didapatkan dengan 1 ditambahkan dengan 155 dikurangi dengan rasio LDR atau LFR dibagi dengan $1 \%$ lalu dikalikan 4. Setelah mendapatkan semua nilai kredit dari masing - masing rasio maka diambil max nilai kredit 100 untuk dikalikan dengan bobot camel. Bobot untuk CAR adalah $25 \%$, bobot untuk KAP $30 \%$, bobot untuk NPM 25\%, bobot untuk BOPO 5\%, bobot

untuk ROA 5\%, dan bobot untuk LDR / LFR $10 \%$. Setelah nilai kredit dikalikan 
dengan bobot maka hasil kali tersebut dijumlahkan semua. Pada akhirnya, akan diperoleh suatu angka nilai CAMEL yang dapat menentukan predikat tingkat kesehatan bank, yaitu Sehat, Cukup Sehat, Kurang Sehat dan Tidak Sehat.

\section{Kerangka pemikiran}

Dalam penelitian ini, variabel kinerja keuangan yang diukur dengan CAMEL disebut sebagai variabel dependen (variabel terikat). Pengungkapan corporate social responsibility disebut sebagai variabel independen (variabel bebas). Model penelitian digambarkan sebagai berikut:

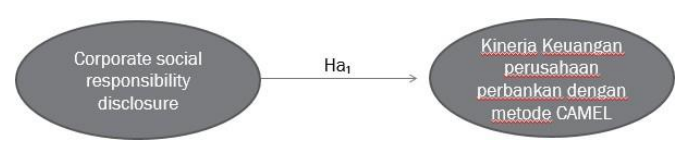

\section{Hipotesis penelitian}

Hipotesis adalah pernyataan yang bersifat dugaan sementara atau jawaban sementara atas permasalahan yang memerlukan data untuk menguji kebenaran dugaan tersebut. Dalam penelitian ini hipotesisnya adalah Pengungkapan CSR berpengaruh positif terhadap kinerja keuangan dengan metode CAMEL pada perusahaan perbankan yang terdaftar di Bursa Efek Indonesia.

\section{METODE PENELITIAN}

Populasi dalam penelitian ini adalah seluruh perusahaan perbankan yang terdaftar pada Bursa Efek Indonesia (BEI). Populasi dalam penelitian ini adalah seluruh perusahaan perbankan yang terdaftar di Bursa Efek Indonesia (BEI) selama periode 2015 - 2017 .

Teknik pemilihan sampel yang diginakan dalam penelitian ini adalah purposive sampling. Menurut Sugiyono (2015) purposive sampling adalah teknik penentuan sampel dengan pertimbangan tertentu. Alasan penggunaan metode purposive sampling didasari atas pertimbangan agar sampel data yang dipilih memenuhi kriteria untuk diuji. Kriteria pemilihan sampel dalam penelitian ini adalah sebagai berikut:
1. Perusahaan yang termasuk ke dalam kategori perusahaan perbankan yang terdaftar di BEI.

2. Perusahaan perbankan yang mengeluarkan annual report pada tahun 2015-2017.

3. Perusahaan perbankan yang mengeluarkan laporan keberlanjutan selama tahun 20152017.

Berdasarkan teknik dan kriteria pengambilan sampel maka sampel yang digunakan berjumlah 11 perusahaan.

\section{HASIL DAN PEMBAHASAN}

Analisis Regresi Linear Sederhana

Analisis regresi linear sederhana bertujuan untuk memprediksi atau menguji pengaruh dari satu variabel bebas yaitu pengungkapan corporate social responsibility dan satu variabel terkait yaitu kinerja keuangan.

\begin{tabular}{|l|l|l|l|}
\hline \multicolumn{2}{|l|}{ Model } & \multicolumn{2}{l|}{$\begin{array}{l}\text { Unstandardized } \\
\text { Coefficients }\end{array}$} \\
\cline { 3 - 4 } \multicolumn{2}{|c|}{} & B & Std. Error \\
\hline \multirow{2}{*}{1} & (Constant) & 80.207 & 3.619 \\
\cline { 2 - 4 } & CSRD & .122 & .094 \\
\hline
\end{tabular}

Sumber : SPSS (2018)

Dari hasil uji t disimpulkan bahwa tidak terdapat pengaruh yang signifikan antara pengungkapan corporate social responsibility terhadap kinerja keuangan maka hasil tabel diatas tidak dapat ditulis persamaan regresinya.

\section{Pembahasan}

Berdasarkan teknik pengambilan sampel menggunakan purposive sampling, diperoleh 11 perusahaan yang memenuhi kriteria. Langkah pertama yang dilakukan dalam penelitian ini adalah uji statistik deskriptif lalu uji asumsi klasik. Berdasarkan hasil dari uji asumsi klasik, pada uji normalitas yang pertama data tidak terdistribusi normal lalu dilakukan uji outlier. Dari hasil uji outlier menunjukkan 3 data atau satu perusahaan yang tidak memenuhi kriteria. Maka sampel yang digunakan dalam penelitian selanjutnya berjumlah 10 perusahaan. 
Langkah selanjutnya dilakukan uji heterokedastisitas, pada uji heterokedastisitas dinyatakan tidak terjadi masalah heterokedastisitas. Selanjutnya dilakukan uji autokorelasi, pada uji autokorelasi dilakukan dengan uji run dan dinyatakan tidak ada autokorelasi.

Setelah lolos dari uji asumsi klasik, dilakukan pengujian data secara parsial serta koefisien determinasi. Hipotesis dari penelitian ini adalah Pengungkapan Corporate Social Responsibility berpengaruh Terhadap Kinerja Keuangan Perusahaan. Berdasarkan pengujian data secara parsial yang dilakukan dengan uji t, diperoleh hasil yang dapat dilihat pada tabel 4.5 yang menunjukkan nilai signifikansi sebesar 0.207 sehingga dapat disimpulkan bahwa variabel CSRD tidak berpengaruh signifikan terhadap variabel kinerja keuangan pada perusahaan perbankan.

Dapat ditarik kesimpulan bahwa hipotesis pertama ditolak. Artinya bahwa dalam penelitian ini pengungkapan corporate social responsibility tidak memiliki pengaruh secara signifikan terhadap kinerja keuangan. Hasil penelitian ini berbeda dengan hasil penelitian dari Naudia et al. (2016) yang menghasilkan hasil bahwa pengungkapan corporate social responsibility berpengaruh terhadap kinerja keuangan pada perusahaan sektor perbankan tetapi tidak terlalu besar hanya 14,6\%. Akan tetapi hasil penelitian ini sama dengan hasil penelitian yang dilakukan oleh Mantaputri dan Widodo (2016) yang menghasilkan hasil bahwa pengungkapan corporate social responsibility tidak berpengaruh signifikan terhadap kinerja keuangan pada perusahaan asuransi.

Pengungkapan corporate social reponsibility yang dilakukan perusahaan perbankan dapat terbilang cukup dikarenakan perusahaan sektor pebankan belum melakukan kegiatan CSR secara berkesinambungan dengan baik setiap tahunnya dan hanya terfokus pada kategori - kategori indikator tertentu yang diukur oleh GRI. Hal tersebut wajar dikarenakan belum adanya penetapan diwajibkan untuk melakukan corporate social responsibility pada perusahaan sektor perbankan oleh pemerintah begitu juga halnya dengan perusahaan asuransi. CSR tidak berpengaruh terhadap kinerja keuangan juga dikarenakan tujuan dari CSR bukanlah untuk memperoleh imbalan financial akan tetapi dengan melaksanakan kegiatan CSR secara konsisten dalam jangka panjang maka akan berdampak menguntungkan pada perusahaan.

Hasil penelitian ini berbeda juga dengan hasil penelitian Suciwati et al. (2016) dan Khitam (2014) yang meneliti pengaruh pengungkapan corporate social responsibility terhadap kinerja keuangan pada perusahaan pertambangan yang menghasilkan hasil bahwa adanya pengaruh signifikan pengungkapan corporate social responsibility terhadap kinerja keuangan pada perusahaan pertambangan. Hasil penelitian Prasetyo dan Meiranto yang meneliti pengaruh pengungkapan corporate social responsibility terhadap kinerja keuangan pada perusahaan manufaktur juga menghasilkan hasil bahwa adanya pengaruh signifikan pengungkapan corporate social responsibility terhadap kinerja keuangan pada perusahaan manufaktur. Hasil penelitian pada perusahaan pertambangan dan manufaktur tentunya dapat berbeda dengan penelitian pada perusahaan perbankan karena pada perusahaan manufaktur dan pertambangan adanya peraturan pemerintah pasal 4 ayat (1) PP No. 47 Tahun 2012 sebagai peraturan pelaksana dari undang - undang pasal 74 ayat (1) UU PT yang mengatur kewajiban bagi perseroan yang berkaitan dengan sumber daya alam untuk melaksanakan tanggung jawab sosial dan lingkungan.

Walaupun corporate social responsibility belum adanya peraturan diwajibkan untuk melakukan pengungkapan corporate social responsibility oleh pemerintah pada perusahaan sektor perbankan dan belum mempengaruhi kinerja keuangan secara signifikan. Akan tetapi corporate social responsibility harus dilakukan dengan kesadaran perusahaan dikarenakan kerusakan lingkungan yang semakin parah akhir - akhir ini maka diperlukan partisipasi perusahaan dalam pelestarian lingkungan.

Pernyataan tersebut didukung 
dengan teori stakeholder bahwa perusahaan bukan entitas yang hanya beroperasi untuk kepentingannya sendiri, namun harus memberikan manfaat bagi stakeholdernya dengan demikian perusahaan perbankan tersebut dapat mempengaruhi keputusan para stakeholder dalam mendukung segala aktivitas perusahaan seperti dalam hal berinvestasi pada penanaman modal dalam bentuk pembelian saham, deposito, membuka tabungan, dan lain-lain. Begitu juga halnya dengan signaling teori yaitu jika perusahaan aktif dalam melakukan corporate social responsibility maka perusahaan melakukan pengungkapan corporate social responsibility dan hal tersebut dianggap sebagai sinyal baik (good news) bagi investor maka terjadi perubahan dalam volume perdagangan saham. Teori legitmasi pun mendukung corporate social responsibility dikarenakan dengan melakukan pengungkapan corporate social responsibility keberadaan dan aktivitas perusahaan terlegitmasi dimana terdapat keselarasan antara nilai - nilai yang melekat pada kegitan perusahaan dengan norma - norma yang ada di dalam sistem sosial masyarakat dimana organisasi adalah bagian dari sistem tersebut. Dimana ketika terjadi ketidak selarasan antara kedua sistem tersebut maka akan ada ancaman terhadap legitmasi perusahaan seperti minat atas produk yang dijual menurun, penjualan saham menurun, dan lain-lain.

\section{KESIMPULAN}

Pengungkapan corporate social responsibility secara parsial tidak berpengaruh signifikan terhadap kinerja keuangan yaitu CAMEL.

Berdasarkan pengujian data yang telah dilakukan, hasil dari penelitian ini menunjukkan bahwa pengungkapan corporate social responsibility yang berasal dari perhitungan GRI-G4 (Global Reporting Initiative 4) untuk menghitung pengungkapan corporate social responsibility tahun 2015 - 2016 dan Standard GRI 2016 untuk menghitung pengungkapan corporate social responsibility tahun 2017 tidak terdapat pengruh yang signifikan terhadap kinerja keuangan yang berasal dari perhitungan CAMEL terdiri atas rasio Capital, rasio Asset, rasio Management, rasio Earning, dan rasio Liquidity dimana dari masing masing rasio diambil nilai kreditnya. Setelah mendapatkan semua nilai kredit dari masing - masing rasio maka diambil max nilai kredit 100 untuk dikalikan dengan bobot camel. Bobot untuk CAR adalah 25\%, bobot untuk KAP 30\%, bobot untuk NPM 25\%, bobot untuk BOPO 5\%, bobot untuk ROA 5\%, dan bobot untuk LDR / LFR 10\%. Setelah nilai kredit dikalikan dengan bobot maka hasil kali tersebut dijumlahkan semua dan didapatlah nilai CAMEL sebagai alat pengukurnya.

Pengungkapan corporate social reponsibility yang dilakukan perusahaan perbankan dapat terbilang cukup dikarenakan perusahaan sektor pebankan belum melakukan kegiatan CSR secara berkesinambungan dengan baik setiap tahunnya dan hanya terfokus pada kategori - kategori indikator tertentu yang diukur oleh GRI. Hal tersebut wajar dikarenakan belum adanya penetapan diwajibkan untuk melakukan corporate social responsibility pada perusahaan sektor perbankan oleh pemerintah. CSR tidak berpengaruh terhadap kinerja keuangan juga dikarenakan tujuan dari CSR bukanlah untuk memperoleh imbalan financial akan tetapi dengan melaksanakan kegiatan CSR secara konsisten dalam jangka panjang maka akan berdampak menguntungkan pada perusahaan di masa yang akan datang. Corporate social responsibility akan terlihat dampaknya baik dalam kinerja keuangan dan lain- lain jika sudah dijalankan dalam jangka panjang. Oleh sebab itu pengungkapan corporate social responsibility dan kinerja keuangan merupakan dua komponen yang penting untuk dikelola secara efektif dan efisien agar tujuan perusahaan untuk memperoleh kinerja keuangan yang baik dapat tercapai.

\section{REFERENSI}

Bank Indonesia. (VII, 2017). Geraiinfo edisi 63. Harus Bisa Membangun Corporate Value. Bank Indonesia dan OJK. (2017). Statistik Perbankan Indonesia. Otoritas Jasa Keuangan. BI. 
(2004). Surat Edaran BI no 6/23/DPNP.

Elkington, J. (1998). Cannibals With Forks: The Triple Bottom Line in 21st Century Business. Oxford: Capstone Publishing Ltd.

Freeman, R. E. (1984). Strategic Management: A Stakeholder Approach. Massachusetts: Pitman. Freeman, R. e. (2010). The Stakeholder Theory: The State of The Art. Cambridge: Cambridge University Press.

Ghozali, I. (2016). Aplikasi Analisis Multivariate dengan Program IBM SPSS 23. Semarang: BPFE Universitas Diponegoro.

Ghozali, I. d. (2016). Teori Akuntansi. Semarang: Badan Penerbit Universitas Diponegoro. GRI. (2016). Retrieved from GRI Empowering Sustainable Decisions:

https://www.globalreporting.org /standards/gri-standardsdownload-center/

Harahap, S. S. (2015). Analisis Kritis atas Laporan Keuangan. (E. 1-10, Ed.) Jakarta: Rajawali Pers. Jakarta, K. (2018, April 19). Retrieved from Koran Jakarta : http://www.koranjakarta.com/permintaan-kreditbaru-melambat/

Kasmir. (2016). Analisis Laporan Keuangan. Jakarta: Raja Grafindo Persada. Khasali, R. (2012). Manajemen Public Relations. Jakarta: PT Pustaka Utama Grafiti.

Khitam, C. (2014). Pengaruh Corporate Social Responsibility (CSR) terhadap Kinerja Keuangan Perusahaan. Jurnal EKBIS.

Kotler, P. a. (2005). Corporate Social Responsibility : Doing the Most Good for Your Company and Your Cause. New Jersey: John Willey and Sons, Inc.

Mantapuri, M. W. (2016). Pengaruh Pengungkapan Corporate Social Responsibility Terhadap Kinerja Keuangan Perusahaan Asuransi yang Terdaftar di BEI Tahun 2010-2014. e-Proceeding of
Management.

Naudia, M. R. (2016). Pengaruh Pengungkapan Corporate Social Responsibility (CSR) terhadap Kinerja Keuangan.

OJK. (2017). Statistik Perasuransian.

Prasetyo, A. M. (2017). Pengaruh Pengungkapan Corporate Social Responsibility Terhadap Kinerja Keuangan Perusahaan Manufaktur yang Terdaftar di BEI Tahun 2013-2015. Diponegoro Journal of Accounting.

Sembiring, E. R. (2005). Karakteristik Perusahaan dan Pengungkapan Tanggung Jawab Sosial: Study Empiris pada Perusahaan yang Tercatat di Bursa Efek Jakarta. Simposium Nasional Akuntansi 8, Universitas Negeri Sebelas Maret

Suciwati, D. P. (2016). Pengaruh Corporate Social Responsibility Terhadap Kinerja Keuangan. Jurnal Bisnis dan Kewirausahaan

Sugiyono. (2015). Metode Penelitian Pendidikan (Pendekatan Kuantitatif, Kualitatif, dan R\&D). Bandung: CV. Alfabeta.

Sukardi. (2014). Metodologi penelitian pendidikan kompetensi dan praktiknya. Jakarta: Bumi Aksara.

Yaparto M, F. D. (2013). Informasi pada laporan keuangan sustainablility report dibutuhkan oleh shareholder karena mengandung informasi tambahan untuk mengambil keputusan dalam melakukan investasi. Jurnal Mahasiswa Universitas Surabaya Vol.2 No.1 